\title{
Sociolingvistika a jazykový management
}

\author{
JIŘí V. NEUSTUPNÝ* \\ Graduate School, Obirin University, Tokio
}

\section{Sociolinguistics and Language Management}

\begin{abstract}
The widest framework available for the treatment of language problems is offered by sociolinguistics. The author of the article begins by introducing sociolinguistics, and claims that one of its four basic thematic clusters, which he calls 'Sociolinguistics IV', is fully devoted to language problems. Mainstream Sociolinguistics, a USbased social network that has made a fundamental contribution to sociolinguistics since the 1960s, developed a version of 'Sociolinguistics IV' that is known as Language Planning. It is in confrontation with Language Planning that the theory of Language Management grew in the 1980s and 1990s. This paper briefly discusses the contribution and problems characteristic of Language Planning and outlines the main features of the Language Management theory. Among these, special attention is paid to the process of language management, which develops out of deviations from norms, whereby some of the deviations are noted, some of the noted deviations are evaluated, and certain adjustment plans are considered and implemented. Finally, the paper suggests that the Language Management theory could perhaps make a valid contribution to other social science disciplines, such as sociology or political science.

Sociologický časopis/Czech Sociological Review, 2002, Vol. 38, No. 4: 429-442
\end{abstract}

Předmětem tohoto článku je teorie jazykového managementu. Tato teorie poskytuje možnost mikroanalýzy i makroanylýzy jazykových problémů a je široce aplikovatelná i na jiné druhy sociokulturních problémů. Teorie jazykového managementu vyrostla na podhoubí jazykového plánování, které se vyvíjelo uvnitř sociolingvistiky od šedesátých let 20. století. Zatímco termín „jazykové plánováni““ organicky navazoval na atmosféru počátku šedesátých let, pojmenování „jazykový management“ (poprvé použito Jernuddem a Neustupným 1987) bylo vybráno arbitrárně a není historicky spojeno s růstem globalizace a ekonomického racionalismu, který zintenzivněl v druhé polovině osmdesátých let a na management kladl důraz. Byl to prostě jeden z použitelných termínů, který jsem v roce 1986 nabídl Björnu Jernuddovi, když jsme jednali o jeho spolupráci na propagaci teorie „jazykové korekce“ [Neustupný 1973, 1977, Jernudd 1982, Jernudd a Thuan 1983] v nové, upravené podobě a pod novou hlavičkou.

V tomto článku chci vysvětlit podstatu teorie jazykového managementu, a to na historickém pozadí. Vyjdu z poznámek o sociolingvistice jakožto nejširším rámci pro tuto teorii, několik odstavců věnuji jazykovému plánování jakožto př́istupu, který tato teorie překonává, a přejdu k charakterizaci teorie jazykového managementu samého.

\footnotetext{
* Veškerou korespondenci posílejte na adresu: Prof. J. V. Neustupný, Graduate School, Obirin University, 2-3-28 Oyamada Sakuradai, Machida, Tokyo 194-0204, Japan, e-mail: RXR13631@nifty.ne.jp
} 


\section{Sociolingvistika}

Dell Hymes kdysi navrhl termín „(socio)lingvistika“, kde závorkami poukazoval na skutečnost, že sociolingvistika je vlastně lingvistika tout court. Lingvistika původně byla odpovědí na problémy spojené s jazykem a teprve později, zvláště v 20. století, se natolik „autonomizovala“, že její původní aplikovatelnost byla pod nánosem abstraktní systematiky obtížně identifikovatelná. V sociolingvistice 60 . let se společenská problematika do lingvistiky vrátila, i když ne vždy jako faktor určující. Někteří američtí sociolingvisté jako William Labov, kteří hledali uznání své práce především u lingvistického establišmentu, se později epiteta „socio“ zřekli.

Sociolingvistika však není výsledkem amerických aktivit z let šedesátých, jak se mnozí domnívají [Paulston, Tucker 1997]. Jednotlivé komponenty sociolingvistiky jako rétorika, stylistika nebo dialektologie existovaly na okraji lingvistiky předstrukturalistické i strukturalistické. V Pražském lingvistickém kroužku byly tyto komponenty velmi silné a vedly na začátku 30. let k založení časopisu Slovo a slovesnost - o němž si mnoho současných lingvistů neuvědomuje, že až do poválečné změny orientace byl časopisem sociolingvistickým [Neustupný 1999a, srov. i Leška, Nekvapil, Šoltys 1993]. Velmi rozsáhlé sociolingvistické zázemí se rovněž projevilo v japonské lingvistice v disciplině „jazykového prožívání“ (časopis Gengo seikacu 1954-1987, srov. [Kraus 1978]). Jak ukázala Hymesova čítanka Language in Society [Hymes 1964], byly jednotlivé prríspěvky hojně zastoupeny jak v USA, tak v jiných zemích.

Nicméně je třeba uznat, že sociolingvistika, která se vyvinula od let šedesátých v USA a v přidružených lingvistických okruzích a kterou budu nazývat „sociolingvistikou hlavního proudu“ (dále SHP), je systémem nejobsáhlejším a teoreticky nejpropracovanějším [Neustupný 1997]. Její východisko lze identifikovat ve dvou oblastech: jednak v záměně paradigmatu strukturalistického poststrukturalistickým [Neustupný 1978], jednak ve snaze USA čelit náporu Sovětského svazu, který se snažil získat mocenský vliv v Asii a v Africe. Bylo jasné, že protiofenzíva je nemožná bez uznání existence společenských (a mezi nimi jazykových) problémů a že toho nelze dosáhnout bez rozvoje sociolingvistického výzkumu.

Problematiku sociolingvistky v její podobě SHP je možné z historického hlediska klasifikovat do čtyř skupin:

\section{(a) SOCIOLINGVISTIKA I (Sociolingvistika vztahu jazyka a společnosti)}

Zde se pojednává o vztahu jazyka a společnosti, tedy o problémech, které normálně laici pokládají za centrum sociolingvistických studií. Tento proud stojí u kolébky SHP, ale z různých důvodů se nerozvinul tak, jak bychom očekávali. Patří sem studium vlivu společnosti na jazyk a naopak, zvláště pak kritika teorií jazykové relativity (reinterpretace Whorfa a Sapira), otázky restriktivních a elaborovaných kódů (B. Bernstein), vliv společnosti na jazykový kontakt (E. Haugen, U. Weinreich), studium posunů v užívání a uchovávání jazyků (shift and maintenance, srov. E. Haugen, J. Fishman), nověji pak např. problémy kritické analýzy diskursu a jazykové ekologie.

\section{(b) SOCIOLINGVISTIKA II (Sociolingvistika jazykové variantnosti)}

Tento typ výzkumu se týká jazykové variantnosti, rozrůzněnosti, tedy otázky, která je centrální ve všech postmoderních myšlenkových systémech. V SHP existuje několik přístupů, 
např. studium variet (dialektů, útvarů) jazyka (J. Gumperz, Ch. Ferguson) a studium jednotlivých proměnných rysů (W. Labov a jeho škola). Pro profesionální sociolingvisty jsou tato studia i dnes centrem jejich discipliny. Ale záběr sociolingvistiky je mnohem širší. Př́inejmenším je v ní třeba přiznat domovské právo i následujícím dvěma okruhům výzkumu.

\section{(c) SOCIOLINGVISTIKA III (Sociolingvistika mimogramatických komponentů komunikace)}

Tento proud je často ztotožňován s Hymesovou etnografií mluvení [Hlavsová 1991, Salzman 1997], ale v letech osmdesátých a devadesátých sem lze zařadit celou lingvistickou „pragmatiku“. Sociolingvistika III je neobyčejně obsáhlá oblast jazykozpytu, která často nebyla ve starši lingvistice zastoupena. Mezi její témata patří funkce použivání jazyka, vlastnosti a konfigurace použivatelů jazyka, otázky obsahu jazykových promluv (témata a motivy, promluvové funkce, zdvořilost apod.), řazení prvků v rozhovoru (sekvenční struktury, srov. Neustupný 1995), způsoby vyjádření (např. celá problematika neverbální komunikace) a podobně. $\mathrm{Z}$ důrazu na kategorie $\mathrm{v}$ ranných pracích $\mathrm{D}$. Hymese se centrum pozornosti přesunulo na studium diskursu, tj. komunikačních procesů. Patří sem dnes výzkum mluvních aktů, stř́idání replik mluvčích apod.

\section{(d) SOCIOLINGVISTIKA IV (Sociolingvistika jazykových problémů)}

Toto je opět velmi široká oblast, kterou je dnes možné ztotožnit se záběrem teorie jazykového managementu. Historicky se však tato oblast rozvíjela pomalu: od jazykového plánování (srov. dále) přes nesmělé pokusy o teorii přeřeknutí k etnometodologii (resp. konverzační analýze) a současně k teorii jazykové korekce v promluvě, zkoumání tzv. jazykových strategií (tj. opravných strategií), jazykových problémů v kontaktních situacích a ovšem ke studiu řešení problémů spojených s osvojováním jazyka.

Tuto klasifikaci výzkumných témat je třeba doplnit klasifikací sociálních systémů (sítí), v nichž se studium realizuje. Pro některá témata je to systém SHP. Avšak řada autorů termín sociolingvistika nepoužívá. Mnoho výzkumů jazykové variantnosti je situováno do kontextu dialektologie, Basil Bernstein se považuje za sociologa pedagogiky, studium neverbální komunikace se ponejvíce provádělo a provádí v sítích psychologie, etnometodologie je součástí sociologie a odborníci v oblasti mluvních aktů, replikové struktury dialogu apod. sami označují svou disciplinu jako „pragmatics“. Situace je ještě složitější, zahrneme-li jiné systémy, které jsou jen marginálně napojeny na SHP a které se často vyvíjely před ní: např. teorie aktuálního členění větného, která spadá pod (c), se rozhodně sama neřadí pod kategorii sociolingvistika.

Zvláštní pozornost v kontextu tohoto časopisu si asi zaslouží otázka, co je to vlastně „sociologie jazyka“. Odpovídám stručně, že jde o sociolingvistiku umístěnou v sítích sociologie. Její centrum by asi mělo být v oblasti, kterou jsem výše nazval sociolingvistika I. Bylo by záslužné, kdyby někdo popsal témata, kterými se sociologové opravdu zabývají. Nemám zde na mysli klasiky sociologie, nýbrž sociology našich generací.

Souhrnně lze říci, že to, co jsme zde zahrnuli do sociolingvistiky, je vlastně celá oblast „věd o jazyce“, s výjimkou gramatických studií, které se tradičně klasifikují zvlášte. 


\section{Jazykové plánování v SHP}

Teorie jazykového plánování se objevila v SHP v šedesátých letech minulého století. Mezi její podněcovatele je třeba zařadit především Charlese Fergusona, který přešel v roce 1959 z Amerického státního departmentu (přes Harvardskou universitu) na místo ředitele nově vytvořeného Centra pro aplikovanou lingvistiku. Ferguson zdaleka nebyl jen řídící pracovník. Byl to nadaný sociolingvista, $\mathrm{s}$ jehož jménem je spojena řada nepostradatelných sociolingvistických pojmů, jako je diglosie nebo „foreigner talk“ (mluvení k cizincům). Kola se začala točit. První důležitá konference byla Language Problems of Developing Nations (Airlie House u Washingtonu, 1966). O rozvojové země skutečně šlo, protože tam byla konkurence se Sovětským svazem největší. „Jazykoví plánovači“ našli svého guru v Einaru Haugenovi, který poprvé použil termín „plánování“ a podstatně přispěl k propracování teorie. Důležitou roli hrál i Joshua Fishman. Haugenovo zaměření na Skandinávii a Ameriku a Fishmanova téměř výlučná orientace na Ameriku však znamenaly, že skutečnými vedoucími byla generace mladší, zaměřená na rozvojové země, k níž patřili Joan Rubinová, Björn Jernudd a také J. DasGupta; ta postupně zahrnovala větší a větší počty pracovníků přímo z rozvojových zemí. U těchto badatelů bylo pojetí jazykového plánování mnohem techničtější. Od roku 1969 se konala řada konferencí spojených s projektem International Research Project on Language Planning Processes a právě v tomto kontextu se dokončilo konstituování teorie jazykového plánování. Snad nejlépe ho lze vyčíst z knihy Can Language Be Planned?, publikované na Hawaii v roce 1971.

Autor tohoto článku se podílel na práci této skupiny jako externí spolupracovník od roku 1966, i když jeho práce se ubírala poněkud jiným směrem - k současné teorii jazykového managementu. Ideologická funce jazykového plánování se neprojevovala př́ímo, zejména když se ujasnilo, že sovětská strana není schopná navrhnout alternativu, která by přilákala vědecké pracovníky rozvojových zemí. Politická funkce jazykového plánování nebyla účastníkům konferencí vưbec zjevná. Nejednou se tam objevily „protiimperialistické“ motivy (Bambose, Khubchandani a jiní); a Jernudd kritizoval Tuckera pro jeho anglofobní doporučení ve věci jazykového vyučování na Arabském poloostrově. V celku však teorie jazykového plánování zůstala konzervativní a nemohla být využita levicovými skupinami. Vyznačovala se následujícími rysy:

\section{Jazykové problémy a společenské problémy}

Jazykové problémy byly chápány jako problémy gramatické kompetence, ve smyslu problémů ,jazyka“ v užším slova smyslu (zahrnující gramatiku, slovník, výslovnost, písmo). Nutnost postupovat ke gramatické kompetenci od společenských problémů přes komunikaci se v diskusích projevovala jen zřídka [Neustupný 1977].

\section{Plánovací sítě}

Jazykové plánování se chápalo jako aktivita v celospolečenském měřítku, na jejímž vrcholu jsou umístěny státní plánovací orgány, bez nichž veškeré akce jsou nemyslitelné. Jazykové plánování se obrací především ke státu a ten považovalo za představitele celé společnosti. Toto chápání mimochodem souhlasilo s povědomím pracovníků z rozvojových společností, na něž se teorie především orientovala. 


\section{Rozsah jazykových problémů}

Jako v tradiční lingvistice jazyk je ztotožněn s „gramatickou kompetenci““. Otázky variantnosti v gramatických prostředcích jsou zahrnuty, ale Sociolingvistika III je v jazykovém plánování popelkou.

\section{Co jsou jazykové problémy}

Problémy jsou identifikovány experty na jazykové plánování. Otázka, jaké problémy mají uživatelé jazyka v konkrétní promluvě [Neustupný 1973], nepřichází ještě v úvahu. Jazykové problémy jsou však chápány nejen jako problémy celých variet a jejich funkcí (status planning) - například zda je určitý jazyk uznán jako jazyk státní administrativy, nýbrž i jako problémy elaborace jednotlivých variet (corpus planning), i když normálně jen v oblasti „gramatické kompetence“. V tomto druhém př́ipadě se např́iklad řeší problémy nedostatků ve slovním fondu nebo problémy zastaralých morfologických kategorií.

\section{5. Řešitelnost jazykových problémů}

Pro jazykové plánování jsou problémy v podstatě řešitelné, pokud experti vládnou správnou teorií a mají podporu státních orgánů. Teprve v letech osmdesátých se u Rubinové objevuje pojem „wicked problems“ [Rubin 1986], ale ani tehdy nepřitahuje mnoho pozornosti.

\section{Proces jazykového plánování}

Jazykové plánování není v podstatě chápáno jako složitý proces. Jak bylo uvedeno výše, problémy jsou identifikovány, načež následuje výběr způsobů jejich řešení a řešení je implementováno. To je vše. Autorovi tohoto článku je znám pouze jeden procesuální model: Haugen 1966. Tento model, o němž lze říci, že upadl v jazykovém plánování v zapomnění, obsahoval „zjištování problémů, posuzování alternativních akčních plánů, rozhodování a implementační způsoby“ [Haugen 1966: 161].

\section{Jazykový management}

Stejně jako jazykové plánování je možné i termín ,jazykový management“ použit (1) o objektivních procesech, které probíhají ve společnosti bez účasti jakékoli organizované teorie, (2) o určité teorii řešení jazykových problémů. V prvním smyslu můžeme mluvit o jazykovém managementu i v rodové společnosti nebo ve středověku. Ve druhém smyslu odkazuje termín primárně $\mathrm{k}$ teorii, která se objevila v letech sedmdesátých pod názvem „teorie jazykové korekce“ jako reakce na nedostatky teorie jazykového plánování [Neustupný 1973, 1978, Jernudd 1982, Rubin 1978-79] a v letech osmdesátých byla rozvinuta pod názvem ,jazykový management“ [Jernudd, Neustupný 1987]. Sekundárně je však do stejné kategorie možné zahrnout i další teorie, které jsou v souladu s teorií managementu v užším slova smyslu. Jde např́íklad o teorii jazykového imperialismu [Phillipson 1992], zbavenou ideologie staré levice, dále o řadu teoretických rysů zachycených v učebnici Kaplana a Baldaufa [1998], o nové teorie záchrany ohrožených jazyků (Fishman), o mnoho poznatků z etnometodologických a konverzačněanalytických výzkumů strukturních problémů rozhovoru počínaje Jeffersonovou [1974] a Schegloffem, Jeffersonovou, Sacksem [1977], dále 
o teorie „jazykových strategií“ (počínaje Taronovou [1981] a Faerchem, Kasperovou [1983]), jakož i některé práce o osvojování jazyka [Long 1983, Rubin 2001]. Kritická analýza diskursu [Fairclough 1995, Chouliaraki, Fairclough 1999] a jazyková ekologie (zvláštní číslo Current Issues in Language Planning, 2000) se rovněž pohybují ve stejném myšlenkovém prostoru. Je ovšem třeba si uvědomit, že autoři těchto teorií termín jazykový management nepouživají a že jde o teorie dílčí. Původní teorie jazykového managementu, propracovaná v jednotlivých oblastech dalšími spolupracovníky, tak zůstává jedinou souhrnnou teorií jazykových problémů.

\section{Jazykové problémy a problémy společenské}

Již ve svém referátu na konferenci v Airlie House [Neustupný 1968] jsem poukázal na rozdíly v hodnotách a zájmech různých aktérů při řešení jazykových problémů a tento názor prostupuje i další moje práce (srov. zvláště [Neustupný 1983], kde jsou zahrnuty v podstatě všechny důležité teze pozdějších redakcí teorie jazykového managementu). Björn Jernudd, který byl původně oddán myšlence jazykového plánování jako objektivní discipliny, přispěl v roce 1987 termínem „zájmy“ (interests), převzatým od Briana Weinsteina [1987]. V kritické odpovědi Weinsteinovi [Jernudd a Neustupný 1987] jsme mluvili o nemožnosti objektivního, „vědeckého“ managementu jazyka, nebot tomu brání rozdílnost zájmů jednotlivých aktérů. V teorii jazykového plánování bylo plánování technickou disciplinou a plánující experti jednali v zastoupení celé společnosti. My jsme tvrdili, že toto není možné.

Zájmy jsou realizovány pouze tehdy, když jejich nositelé vlastní také moc („power“). Otázky moci nebyly v původní teorii jazykového managementu rozvinuty a jiní jako Fairclough [1989], Tollefson [1991], či Phillipson [1992] zde mají prioritu, ačkoli se pohybují v rámci ideologického systému, který lze označit jako „stará levice“. V mé vlastní práci se objevuje „moc“ ve větším měřítku v roce 1996 [Neustupný 1966].

Teorie jazykového managementu postuluje, že řešení jazykových problémů musí začít řešením přidružených problémů společenských a komunikativních (Neustupný 1977). Ve studii Neustupný (1993) jsem navrhl pojem „problémový cluster“; viz z tohoto hlediska např́iklad problematiku romštiny v tehdejším Československu:

SE: Ztráta tradiční kultury

SL: Ztráta situací používání romštiny

GR: Posuny v uživání jazyka (shift)

$(\mathrm{SE}=$ socioekonomická rovina, $\mathrm{SL}=$ sociolingvistická rovina, $\mathrm{GR}=$ rovina gramatické kompetence)

\section{Sítě jazykového managementu}

Zatímco jazykové plánování se obracelo hlavně na stát jako zástupce společnosti, v teorii managementu je zdůrazněn fakt, že jazykové problémy jsou předmětem akce na nejrůznějších úrovních: na úrovni státu, jeho jednotlivých odvětví (například v místní samosprá- 
vě), v systému výchovném, v jednotlivých organizacích (ekonomických, společenských, kulturních) a na úrovni jednotlivců. V posledním př́ípadě nejde jen o účast jednotlivců v akcích na celostátní úrovni - to už zdůrazňoval Einar Haugen, když mluvil o Aasenovi, Dobrovském a jiných - ale i na úrovni „soukromého“ managementu jazyka jednotlivce.

\section{Rozsah jazykových problémů}

Programový záběr jazykového managementu je velmi široký. Jak už jsem naznačil výše, zahrnuje nejen problémy „gramatické kompetence“, nýbrž i problémy jazyka ve smyslu „komunikace“, tedy problémy, které jsem výše označil jako Sociolingvistika III . Zahrnuje rovněž odchylky od norem, které jsou vyhodnocovány pozitivně a působí proto nikoli „problémy“, nýbrž jejich opak, jev, který je mimochodem obtížné nazvat (v článku Neustupný, v tisku, jsem ho nazval „gratifikace“). Např́iklad pozitivní hodnocení neznámého jazyka může vést $\mathrm{k}$ rozhodnutí takový jazyk si osvojit. Je přirozené, že v letech šedesátých, v návaznosti na odumírající strukturalismus, který - všeobecně řečeno - „problémy“ odsunoval na vedlejší kolej, jsme existenci problémů zdůrazňovali. To by však nemělo platit o počátku tohoto století, kdy negativně hodnocené odchylky od norem (tzn. problémy) jsou všeobecně uznávány a kdy společnost mnoha zemí je ideologicky připravena existenci pozitivních hodnocení přijmout.

\section{Co jsou jazykové problémy}

Teorie jazykového managementu klade velký důraz na mikroanalýzu a zde se stýká s etnometodologií. U teorie jazykového managementu je zdůrazněno, že původ všech jazykových problémů je v mikrojevech na úrovni promluvy. Tato teze je občas interpretována tak, že všechny jazykové problémy vycházejí z komunikačních nedorozumění, ale tak tomu samozřejmě není. Jazykové promluvy neplní jen funkci komunikační, nýbrž i symbolickou, společensko-ekonomickou a jinou. Tak se stává, že mluvčí například pocit’ují v interakci (promluvě) nejen to, že nemohou vyjádřit určitý obsah, nýbrž i to, že jazykem nedostatečně komunikují svou loajálnost k národu nebo že jazyk vytváŕí sítě, které jsou pro mluvčího nepříznivé (např. v určité konkrétní situaci angličtina socioekonomicky zvýhodňuje rodilé mluvčí angličtiny a státy anglofonního typu). Odtud pak vycházejí diskuse a usnesení jazykové politiky, které povyšují jazyk na národní jazyk nebo se snaží omezit vliv angličtiny. Prostě jazykový problém musí být lokalizován v interakci, z níž pak vycházejí jazykové postoje, které jsou rozvedeny v oblasti ideologie a zpětně působí na jazykový management.

Z jednotlivých interakčních aktů se managementové procesy skládají v organizované akce, v nichž se projevuje teorie a ideologie, vytvářejí se rozsáhlé sítě a probíhají složité procesy. Zde už nemusí být spojení s konkrétními interakčními akty zřetelné. Teorie jazykového managementu však požaduje, aby toto spojení bylo co nejsilnější. Jinými slovy, jazykový management se musí odpoutat od situace, kdy lingvisté či jiný personál určovali na základě velmi omezené zkušenosti z jazykové praxe, co je, či není problém. Ukázkou nejsložitějších systémů organizovaného managementu je vyučování jazyků nebo jazyková politika. 


\section{5. Řešitelnost jazykových problémů}

Na rozdíl od jazykového plánování se teorie jazykového managementu vyznačuje realistickým postojem k řešitelnosti jazykových problémů. Poukazuje sice na to, že některé problémy nepochybně řě̌ení nemají, ale na druhé straně věří, že mnoho problémů řešit lze.

\section{Management jako proces}

Pravděpodobně základním přínosem teorie jazykového managementu je její procesuálnost. Předpokládá se, že všechny managementové procesy probíhají v podstatě následujícími pěti stádii.

(1) V interakční situaci vznikají odchylky od norem jednání (deviation).

(2) Těchto odchylek si mluvčí povšimnou (noting).

(3) Takové odchylky hodnotí negativně či pozitivně (evaluation).

(4) Za účelem úpravy hodnocených odchylek vybírají akční plán (adjustment design)

(5) a ten realizují (implementation).

Důležité je to, že proces managementu může být ukončen v kterémkoli stádiu. Např́iklad v interakci se objeví odchylky od norem, ale nikdo si jich nepovšimne. Nebo odchylky mohou být povšimnuty, ale nejsou hodnoceny apod.

\section{Otázky norem}

Propracovaný pojem jazykové normy pochází z Pražské školy [Havránek 1938, Daneš 1987]. Tento pojem byl nejen obecně přijat, ale později se stal i předmětem skepse. Dnes se diskuse musí vyrovnávat s námitkami, že normy jsou vlastně nově vytvářeny v každé konkrétní situaci. Lingvisté patří mezi ty specialisty ve společenských vědách, kteři se necítí ohroženi, když někdo namítne, že normy vlastně neexistují. Existence jazykových norem je totiž nad jakoukoli pochybnost. Zároveň je však možné, že v oblasti sociokulturních procesů je charakter norem poněkud odlišný. V každém př́padě je nutné uznat, že normy jsou variabilní a dynamické, a to i normy gramatické kompetence.

Zvláštní význam mají normy v kontaktních situacích (kam patř́i všechny situace osvojování jazyka), protože $\mathrm{v}$ nich se zcela jasně uplatňuje norem několik, počítaje $\mathrm{v}$ to i normy specifické pro kontaktní situace (například vůči cizím mluvčím je povoleno používat tzv. foreigner talk, tj. specifické mluvení k cizincům). Ale př́itomnost několika systémů norem v téže situaci necharakterizuje jen situace kontaktní. To se výrazně projevuje v organizovaném managementu, kde se často o „správných normách“ komunikace vedou diskuse.

Jaké normy v určité situaci existují a jak se tyto normy od situace k situaci vyvíjejí, je empirická otázka, kterou nelze řešit dohady. Zejména pokud se týká mimogramatických komponentů komunikace, je třeba očekávat, že budoucí výzkum prrinese překvapení, která budou mít důsledky i pro organizovaný management [Kato 2002]. 


\section{Otázky odchylek od norem}

Odchylkami se rozumí to, že lidské jednání není v souladu s normami. Odchylky ještě neznamenají, že se jedná o problémy, ale jsou podmínkou pro jejich vznik.

\section{Otázky povšimnutí}

Povšimnutí je pro jazykový management velmi důležité. Pokud si účastníci interakce nepovšimnou, že došlo $\mathrm{k}$ odchylce, zůstává tato odchylka jen potenciálním problémem. Mnohdy skutečně k povšimnutí nedochází. Například v kontaktních situacích zůstávají určité odchylky (například ve výslovnosti) nepovšimnuty, zatímco jiné (v systému zdvořilosti) jsou předmětem intenzivního registrování. Pro osvojování jazyka to znamená, že se musí soustředit především na odchylky od norem, které jsou předmětem intenzivního povšimnutí.

Povšimnutí je nejen vědomé, nýbrž i polovědomé a možná i zcela nevědomé. O povšimnutí v promluvě čerpáme informace nejen z vědomých reakcí (naprríklad z toho, co říkají účastníci v následných interview, srov. Neustupný 1999b), nýbrž i z tzv. neverbálních signálů, jako jsou výraz tváře, pohyby rukou a podobně. Někdy se o povšimnutí dovíme teprve z dalšího jednání, které je na něm založeno, například z faktu, že dochází ke korekci či k osvojení.

Pokud se týká organizovaného managementu, zdrojem povšimnutí jsou výzkumy jazykové situace. Velmi často však k systematickým výzkumům nedochází a jazyková politika se pak zakládá na neformálních povšimnutích personálu, který je s jazykovou politikou nejúžeji spjat. Takovou situaci teorie jazykového managementu kritizuje. Skutečnost, že v interakci vůbec nedošlo k povšimnutí, však neznamená, že bychom měli odchylky od norem ignorovat. Takové odchylky mohou být povšimnuty a stát se předmětem managementu v bezprostřední budoucnosti. Avšak pokud se tak nestane, je jejich status odlišný.

\section{Otázky hodnocení}

I když došlo k povšimnutí, neznamená to automaticky, že mluvčí odchylku hodnotí. V interakci se často objevují postoje jako „ano, všimnul jsem si, ale o to mi vůbec nejde“ a tyto postoje jsou potvrzeny další evidencí. Často však k hodnocení dochází. Můžeme rozlišovat negativní a pozitivní hodnocení, mající nejrůznější intenzitu. Pokud došlo k negativnímu hodnocení, je možné mluvit o existenci problému. O pozitivních hodnoceních už jsem se zmínil. Stejně jako v případě povšimnutí nejsou ani hodnocení vždy plně vědomá a o jejich zjištění ve výzkumu platí totéž jako o povšimnutí.

Na úrovni organizovaného managementu dochází $\mathrm{k}$ hodnocení v diskusích, které někdy probíhají v rozsáhlých sítích účastníků. Často existuje protiklad mezi organizovaným hodnocením a hodnocením $\mathrm{v}$ interakci. Například v organizovaném jazykovém plánování se často negativně hodnotí to, že menšiny nemohou použivat vlastní jazyk jako jazyk vyučovací, ale k podobnému hodnocení ne vždy docházejí sami členové příslušných komunit. 


\section{Otázky akčního plánu}

V př́ipadě jazykového managementu existují nejrůznější korekční plány, počínaje opakováním výrazu, volbou jiného výrazu či zesílením kontroly zdvořilosti. Do stejné oblasti patří v případě osvojování všechny „learner strategies“ [Oxford 1990]. Akční plány (korekční formáty) upoutaly pozornost mnoha badatelů (naprríklad v etnometodologii, resp. konverzační analýze, nebo v teorii jazykové akvizice).

U organizovaného managementu jsou akčními plány například návrhy na jazykovou reformu nebo sylaby jazykových kursů. Zde jsme již v oblasti, která byla alespoň částečně pokryta $\mathrm{v}$ jazykovém plánování.

\section{Otázky realizace}

Je, myslím, zřetelné, že plány nejsou realizovány automaticky. Problémy jsou u promluvového managementu $\mathrm{v}$ nedostatku času, přerušení jiným mluvčím nebo $\mathrm{v}$ neschopnosti mluvčího realizovat rutinní průběhy. U organizovaného managementu je implementace často obtížná, protože vyžaduje zvláštní sítě, rozpočty a především moc (power) implementaci realizovat. Historie organizovaného managementu je zaplněna prrípady, kdy perfektně formulované akční plány zůstaly neimplementovány, protože k tomu chyběly podmínky.

\section{Složitějši formy managementového procesu}

Proces managementu může být složitější než schéma uvedené v předchozích paragrafech. Typickým př́íkladem je „vyjednáváni““ (negotiation), které je v literatuře uváděno už po dlouhou dobu [např. Gumperz 1982], ale k jehož podrobné sekvenční analýze dochází teprve mnohem později [srov. částečně Miyazaki 1997, 2001].

Teorie jazykového managementu se dnes používá v nejrůznějších oblastech zkoumání jazyka. Jedná se nejen o oblast kontaktové lingvistiky [např. Fan 1994, Fairbrother 2000, Nekvapil 2001] a osvojování jazyka [Muraoka 2000], nýbrž i o studium jazyka ve speciálních situacích [Marriott 1991] nebo studium akvizice akademické kompetence [Marriott 2000]; pojmu jazykový management se rovněž užívá k charakterizaci jazykového vývoje [Nekvapil 2000].

\section{Metodologie jazykového managementu}

Studium jazykového managementu vyžaduje metodologii, která se dosud v jazykovědě zcela neprosadila. Je třeba zjistit, kde a jak dochází k povšimnutí, hodnocení, jaké plány jsou vybírány a jaké problémy se objevují při implementaci. Nejdůležitější jsou zde nejrůznější formy introspekčních metod, jako je následné interview [Neustupný 1999b]. 


\section{Od jazykového managementu k managementu sociokulturnímu}

Vrat'me se v závěru stručně k otázce aplikovatelnosti teorie jazykového managementu na jiné společenské vědy. Myslím, že zde existuje možnost aplikace na nejrůznější případy, kde analýza problémů je zvláště naléhavá. Jde především o otázky diskutované v sociologii, politologii a přidružených disciplinách. Ve všech těchto případech se pojednává o dynamických normách, od nichž vznikají odchylky, které jsou následně povšimnuty, hodnoceny a výsledkem jsou akční plány určené k realizaci. Podrobnější úvahy o tomto tématu mi však nepř́ísluší.

JiŘí V. NeUSTUPNÝ studoval na Karlově univerzitě a po několikaletém působení v Orientálním ústavu ČSAV odešel v roce 1966 na Monašovu universitu v Melbourne, kde vedl katedru japonských studii až do roku 1993. Pak přesídlil do Japonska a zde vyučoval aplikovanou lingvistiku na Ósacké universitě a Universitě v Čibě; v současné době působí na universitě Óbirin $v$ Tokiu. Zajímá se o jazykové a interakční problémy ve všech formách: od jazykové politiky pres problémy kontaktních situací až po vyučování cizích jazyků. Vydal řadu knižních a časopiseckých publikací. Jeho poslední kniha pojednává o metodologii v jazykovědném výzkumu.

\section{Bibliografie}

Daneš, F. 1987. Langue standard et culture de la langue. Pp. 454-492 in J. Maurais (ed.), Politique et aménagement linguistiques. Québec: Conseil de la langue française.

Faerch, C., G. Kasper 1983. Strategies in Interlanguage Communication. London: Longman.

Fairbrother, L. 2000. Analysis of intercultural interaction management within a party situation. The Japanese Journal of Language in Society 2/2: 33-44.

Fairclough, N. 1995. Critical Discourse Analysis. London: Longman.

Fairclough, N. 1989. Language and Power. London: Longman.

Fan, S. K. 1994. Contact situations and language management. Multilingua 13/3: 237-252.

Gumperz, J. J. 1982. Discourse Strategies. Cambridge University Press.

Haugen, E. 1966. Linguistics and Language Planning. Přetištěno v E. Haugen, pp. 159-186. The Ecology of Language. Stanford: Stanford University Press, 1972.

Havránek, B. 1938. Zum Problem der Norm in der heutigen Sprachwissenschaft und Sprachkultur. Pp. 151-156 in Actes du Quatrième Congrès International des Linguistes. Copenhagen.

Hlavsová, J. 1991. Konflikt jako forma kontaktu. Slovo a slovesnost 52: 256-263.

Hymes, D. H. (ed.) 1964. Language in Culture and Society. New York: Harper and Row.

Chouliaraki, L., N. Fairclough 1999. Discourse in Late Modernity. Edinburgh: Edinburgh University Press.

Jefferson, G. 1974. Error correction as an interactional resource. Language in Society 2: 181-199.

Jernudd, B. H. 1982. Language planning as a focus for language correction. Language Planning Newsletter 8, 4: 1-3.

Jernudd, B. H., J. V. Neustupný 1987. Language planning: for whom? Pp. 69-84 in Proceedings of the International Colloquum on Language Planning, ed. by L. Laforge. Quèbec: Les Presses de l'Université Laval. 
Jernudd, B. H., E. Thuan 1983. Control of language through correction in speaking. International Journal for the Sociology of Language 44: 71-97.

Kaplan, R. B., R. B. Baldauf 1998. Language Planning from Practice to Theory. Clevendon: Multilingual Matters.

Kato, Y. 2002. Intabyu sesshoku bamen ni okeru „kihan“ no kenkyu [Studium norem v kontaktních situacích typu interview]. Tokai daigaku kiyo (Ryugakusei kyoiku senta) 22: 21-40.

Kraus, J. 1978. O jazykové kultuře a jazykové výchově v Japonsku. Naše řeč 61: 44-47.

Leška, O., J. Nekvapil, O. Šoltys 1993. Ferdinand de Saussure and the Prague Linguistic Circle. Pp. 9-50 in Chloupek, J., J. Nekvapil (eds.) Studies in Functional Stylistics, Amsterdam, Philadelphia: John Benjamins.

Long, M. 1983. Native speaker/non-native speaker conversation and negotiation of comprehensible input. Applied Linguistics 4/2: 126-141.

Marriott, H. E. 1991. Language planning and language management for tourism shopping situations. Australian Review of Applied Linguistics, Series S, No. 8: 191-222.

Marriott, H. E. 2000. Japanese students' management processes and their acquisition of English academic competence. Journal of Asian Pacific Communication 10, 2: 279-296.

Miyazaki, S. 1997. Communicative Adjustment Between Native and Non-Native Speakers of Japanese. $\mathrm{PhD}$ dissertation, Monash University, Melbourne.

Miyazaki, S. 2001. Theoretical framework for communicative adjustment in language acquisition. Journal of Asian Pacific Communication 11, 1: 39-60.

Muraoka, H. 2000. Management of intercultural input. Journal of Asian Pacific Communication 10, 2: 297-312.

Nekvapil, J. 2000. Language management in a changing society. Pp. 165-177 in Baldur Panzer, Hrsg. Die sprachliche Situation in der Slavia zehn Jahre nach der Wende. Frankfurt am Main: Peter Lang.

Nekvapil, J. 2001. Jazykový management a etnická společenství v České republice. Pp. 65-80 in Přednášky z XLIV. běhu Letní školy slovanských studií. Praha: Univerzita Karlova, Filozofická fakulta.

Neustupný, J. V. 1968. Some general aspects of „language“ problems and „language“ policy in developing societies. Pp. 285-294 in Language Problems of Developing Nations, ed. by J. A. Fishman, C. A. Ferguson and J. Das Gupta. New York: J. Wiley.

Neustupný, J. V. 1973. An outline of a theory of language problems. Paper prepared for VIIIth World Congress of Sociology. Tištěná forma v Neustupný 1978, jako kapitola 12.

Neustupný, J. V. 1977. Language planning for Australia. Language Sciences 45: 28-31.

Neustupný, J. V. 1978. Post-Structural Approaches to Language. Tokyo: University of Tokyo Press.

Neustupný, J. V. 1983. Towards a paradigm for language planning. Language Planning Newsletter 9, 4: $1-4$.

Neustupný, J. V. 1993. Language management for Romani in Central and Eastern Europe. New Language Planning Newsletter 7, 4: 1-6.

Neustupný, J. V. 1995. Some issues of ordering in interactive competence. Pp. 10-26 in B. Palek (ed.), Proceedings of LP'94: Item Order in Natural Languages - Prague 16-18 August 1994. Prague: Charles University Press.

Neustupný, J. V. 1996. Current issues in Japanese-foreign contact situations. Pp. 208-216 in Kyoto Conference on Japanese Studies 1994, Vol. II. Kyoto: International Research Center for Japanese Studies. 
Neustupný, J. V. 1997. Sociolinguistics: Some other traditions. Pp. 201-209 in Paulston, Tucker 1997.

Neustupný, J. V. 1999a. Sociolinguistics and the Prague School. Prague Linguistic Circle Papers (Travaux du Cercle linguistique de Prague, nouvelle série). Vol. 3: 275-286.

Amsterdam/Philadelphia: John Benjamins.

Neustupný, J. V. 1999b. Následné (follow-up) interview. Slovo a slovesnost 60/1: 13-18.

Neustupný, J.V. (v tisku). Japanese students in Prague: Problems of communication and interaction. International Journal of the Sociology of Language 162.

Oxford, R. L. 1990. Language Learning Strategies. New York: Newbury House Publishers.

Paulston, C. B. a G. R. Tucker 1997. The Early Days of Sociolinguistics. Dallas: The Summer Institute of Linguistics.

Phillipson, R. 1992. Linguistic Imperialism. Oxford: Oxford University Press.

Rubin, J. 1978-1979. The approach to language planning within the United States. Language Planning Newsletter 4, 4, 1-6, 5, 1, 1-6.

Rubin, J. 1986. City planning and language planning. Pp. 105-122 in Language Planning, Proceedings of an Institute. Mysore: CIIL.

Rubin, J. 2001. Language learner self-management. Journal of Asian Pacific Communication 11, 1: 25-37.

Salzman, Z. 1997. Jazyk, kultura a společnost. Úvod do lingvistické antropologie. Praha: Ústav pro etnografii a folkloristiku AV ČR.

Schegloff, E. A., G. Jefferson, H. Sacks 1977. The preference for self-correction in the organization of repair in conversation. Language 53: 361-382.

Tarone, E. 1981. Some thoughts on the notion of ,communicative strategy'. Přetištěno v Faerch, Kasper 1983, pp. 61-74.

Tollefson, J. W. 1991. Planning Language, Planning Inequality. London: Longman.

Weinstein, B. 1987. Language planning and interests. L.Laforge, ed. Proceedings of the International Colloquium on Language Planning, pp. 33-58. Québec: Les Presses de l'Université Laval.

\section{Summary}

Sociolinguistics can be divided into four thematic clusters: (I) sociolinguistics of the relationship between language and society (overlapping with the lay view of sociolinguistics), (II) sociolinguistics of language variation (the majority conception of the discipline in the case of professional sociolinguists), (III) sociolinguistics of non-grammatical communication (so-called ethnography of communication, pragmatics, etc.) and (IV) sociolinguistics of language problems. Under IV, the approach called Language Planning developed in the 1960s and 1970s, and gained wide currency both among theoreticians and practitioners. An alternative approach, called Language Management (based on an earlier theory of 'language correction') emerged during the 1980s, mainly on the basis of the work of Neustupný and Jernudd. It is possible to place within the same category the less general theories of critical discourse analysis, linguistic imperialism, language ecology, saving threatened languages (Fishman), much of the linguistic ethnomethodology (commencing with Jefferson, Sacks, etc.), theories of linguistic strategies (in language acquisition, cf. Tarone, Faerch, Kasper, etc.), and some other approaches (cf. Kaplan and Baldauf's textbook). Such approaches do not use the term Language Management but share some of the features of this framework. These features can be outlined as follows:

1. A close relationship between language and social problems. This includes the issues of differential values of distinct social groups, group interests and power, as well as the issues of language 
rights. One of the basic requirements is that the solution of language problems must start with an attention to social problems. Communication problems follow suit, and language problems in the narrow sense (problems of 'grammatical competence') come last.

2. Attention to language problems must not be limited to governmental and other society-wide networks. A strong emphasis on governmental networks was characteristic for the traditional Language Planning. However, there are many other levels, including the level of language teaching, economic and social organisations, and the individual.

3. The range of language problems is seen as very wide, including not only problems of grammatical competence, but also problems of non-grammatical communication, as delineated in Sociolinguistics III. Along with negative evaluations (problems), the examination of positive evaluations of language is required.

4. Language problems are not what Language Planning experts consider as such. They are seen as originating in individual acts of interaction at the microlevel, where not only the communicative function but also the symbolic and other social functions matter. This is 'simple management'. On the other end of the spectrum is 'organised management', such as management by governmental committees, which in fact originates on the microlevel, but uses complicated networks, ideologies and management acts that add new aspects to the management process.

5. The language management theory assumes that some problems definitely have no solutions. Rubin's 'wicked problems' come to mind. But other problems can be solved, and it is essential that this fact be clearly demonstrated in each case.

6. One of the basic issues is the clarification of the process of language management. The stages are (a) deviations from norms, (b) noting, (c) evaluation, (d) adjustment design, and (e) implementation. The management process moves along this line but it can be interrupted at any stage. There are deviations from norms that remain unnoted, noted deviations that are not evaluated, and evaluated deviations that remain unadjusted.

This paper further discusses some key issues of each of these stages of the language management process. 